\author{
돼지 Duroc 품종에서 미토콘드리아 유전체 서열의 특성과 \\ 집단의 유전적 다양성 \\ 조인철* . 한상현* . 최유림* . 고문석* . 이정규*** . 이준헌** · 전진태*** \\ 농촌진흥청 난지농업연구소*, 충남대학교 동물자원학부**, 경상대학교 응용생명과학부***
}

\title{
Complete Mitochondrial Genome Sequence and Genetic Diversity of Duroc Breed
}

\author{
I. C. Cho*, S. H. Han*, Y. L. Choi*, M. S. Ko*, J. G. Lee***, J. H. Lee** and J. T. Jeon*** \\ National Institute of Subtropical Agriculture, R.D.A.*, \\ Division of Animal Science and Resources, Chungnam National University**, \\ Division of Applied Life Science, Gyeongsang National University, Jinju 660-701, Korea***
}

\begin{abstract}
Duroc is widely used to improve the meat quality and productivity. To elucidate the phylogenetic relation and the sequence specificity for the maternal property, the complete sequence of mitochondrial genome was determined and the population diversity of Duroc was investigated in this study. The length of mtDNA tested is 16,584-bp. There are several insertion/deletion mutations in the control region and coding regions for tRNA and rRNA, respectively, but not in peptide-coding regions. Four peptide-coding genes(CO //, CO///, ND3 and ND4) showed incomplete termination codon sequences such as T--, and two(ND2 and ND4L) did alternative initiation codons(AIC), respectively. Especially, the initiation codon sequences of ND2 gene were polymorphic in this population. Polymorphisms were detected in 11-bp duplication motif within control region as well as ND2 and CYTB. Variation patterns observed from the tests on three mtDNA regions were linked completely and then two haplotypes obtained from combining the data dividing this population. Duroc mtDNA is observed at the European pig cluster in the phylogenetic tree, however, the results from the population analyses supported previous opinions. This study suggests that the breed Duroc was mainly originated from the European pig lineage, and Asian lineage was also used to form the pig breed Duroc as maternal progenitors.
\end{abstract}

(Key words : Duroc, Haplotype, Maternal origin, Mitochondrial genome, Sus scrofa)

$$
\mathrm{I} \text { 서 론 }
$$

돼지의 가축화 시기는 기원전 $6,000 ~ 9,000$ 년 전으로 추정되며 아시아와 유럽에서 독립적으로 진행되었으며, 유럽돼지 품종을 개량하기 위하여 18 19세기 초에 중국 돼지들이 유럽에 전파되어 돼지 육종과정에 유입된 것으로 보고 있다 (Bökönyi, 1974; Watanabe 등 1985; Jones, 1998).
포유동물의 미토콘드리아 DNA는 환상(circular) 의 이중나선 $\mathrm{DNA}$ 로 길이는 약 $16 \sim 17.5-\mathrm{kb}$ 정도이며, 2종류의 ribosomal RNA 유전자, 13 종류의 peptide coding gene, 22 종류의 transfer RNA 유전자와 조절영역인 D-loop으로 구성되 어 있다(Anderson 등, 1981; Ursing과 Arnason, 1998; Lin 등, 1999; Kijas와 Andersson, 2001; Yang 등, 2003). 미토콘드리아 DNA의 모계유

Corresponding author : J. T. Jeon, Division of Applied Life Science, Gyeongsang National University, Jinju 660-701, Korea. Tel : 055-751-5516, E-mail : jtjeon@nongae.gsnu.ac.kr 
전 특징과 핵 DNA에 비해 10배 이상 빠른 염 기치환율을 이용한 DNA 다형성에 근거한 종 간 또는 종내 유연관계 분석과 진화과정 중 모 계의 이동경로를 추적하는 좋은 자료가 되고 있다(Brown 등, 1979; Giles 등, 1980; Cann 등, 1984; Wilson 등, 1985).

현재까지 돼지 미토콘드리아 DNA 서열에 대한 연구 자료들은 다양한 가축돼지 품종들의 기원과 유래 등을 설명하는 분자생물학적 정보 들을 제공하였다. 조절부위인 D-loop과 $12 \mathrm{~S}$ 리 보솜 RNA 유전자, cytochrome $\mathrm{B}(C Y T B)$ 유전자 등의 다형성과 haplotype에 관한 연구들은 가축 돼지 형성과정과 진화, 중국돼지의 유럽 유입 과정을 설명하는 분자적 증거들로 제시되고 있 다(Okumura 등, 1996; Giuffra 등, 2000; Kim 등, 2002; Alves 등, 2003; Watanobe 등, 2004). 돼지 mtDNA의 전체서열은 Ursing과 Arnason (1998)에 의해 최초로 보고되었고, 이후 Duroc, Landrace, Large White, 유럽산 멧돼지(Italian wild boar, Swedish wild boar), 중국산 재래돼지 17 품종의 near complete sequence들이 밝혀졌 으며, 이를 바탕으로 돼지의 가축화 시기와 품 종 간 유연관계가 재조명되었다.

Duroc 품종의 기원은 미국 New Jersey와 New York을 중심으로 한 미 동부지방이 원산 지이며, 19세기에 수입된 서아프리카, 스페인, 포르투갈 원산의 적색 대형종인 Jersey Red와 적색 Duroc을 교배하여 Duroc Jersey로 만들어 품종을 등록하였다. 이후 Duroc 품종이라 불리 고 있으며, 모색은 적갈색이나 색의 농도는 많 이 차이가 있다. Kijas 등(1998, 2001)과 Giuffra 등(2000)은 돼지 $M C 1 R$ 유전자 분석에서 Duroc 품종의 적모색은 $M C 1 R^{*} 4(e$, recessive red)의 대 립유전자형에 의해 발현되는 것으로 보고하였 다. mtDNA D-loop과 CYTB 유전자 서열을 기 준으로 한 haplotype 분석에서 Duroc 품종은 몇 가지 haplotype들로 구분되고, 모계선조로써 유 럽 돼지뿐만 아니라 아시아 돼지에 의한 영향 이 있었을 것으로 추정되고 있다(Giuffra 등, 2000; Okumura 등, 2001; Alves 등, 2003; 조 등, 2003).

본 연구에서는 다른 돼지 품종에 비해 산육
성이 우수한 Duroc 품종에서 미토콘드리아 DNA 전체 서열을 결정하고 이를 여러 돼지 품종에 서 보고된 서열들과 비교하여 모계 유연관계를 추정하였다. 또한, Duroc 품종 집단의 유전적 다양성과 모계 선조집단의 기원을 규명하기 위 하여 $\mathrm{mtDNA}$ 의 D-loop, $\mathrm{ND} 2, \mathrm{CYTB}$ 유전자의 다형성에 근거한 mtDNA haplotype의 유형을 분석하였다.

\section{재료 및 방법}

\section{1. 공시동물 및 DNA 추출}

본 연구에 공시한 돼지는 유럽(Denmark)과 미주지역(Canada)에서 도입하여 현재 농촌진흥 청 난지농업연구소에서 사육하고 있는 Duroc 품종을 공시하였다. 미토콘드리아 유전체 전체 서열 결정은 1 두를 분석하였으며, 유전적 변이 가 발견된 부위를 중심으로 총 125 두를 공시하 였고, 대조집단으로 Landrace(40두)와 Large White (76두)를 공시하여 비교분석에 이용하였다. Genomic DNA 추출은 비보정법으로 경정맥에 서 혈액을 채혈하여 sucrose-proteinase $\mathrm{K}$ 방법 (Birren 등, 1997)으로 추출하였다. 추출한 DNA 는 RNase(Sigma, USA) 처리와 phenol extraction 으로 정제한 후 ethanol 침전법으로 회수하였 다. 회수한 DNA는 TE buffer에 용해하였고 PCR 증폭을 위한 주형으로 이용하였다.

\section{Duroc mtDNA PCR 증폭}

돼지 Duroc 품종의 mtDNA 서열 결정은 $\mathrm{Lin}$ 등 (1999)에 의해 보고된 Landrace 서열(NC_000845) 을 기준으로 PCR을 위한 primer를 고안하여 14 개의 단편으로 나누어 증폭하였다. PCR 증폭 은 $10 \times$ 반응 완충액(20 mM Tris-HCl, $\mathrm{pH}$ 8.0; $100 \mathrm{mM} \mathrm{KCl}$; $0.1 \mathrm{mM}$ EDTA), $20 \mathrm{mM}$ dNTP, 각각 $200 \mathrm{mM}$ primer, 1.5 units Taq DNA polymerase(TaKaRa, Japan)와 $100 \mathrm{ng}$ genomic DNA 용액에 멸균한 탈이온수를 첨가하여 $25 \mu \ell$ 용량 으로 반응하였다. PCR 증폭은 GeneAmp PCR System 9600 Thermal Cycler(Perkin-Elmer, USA) 
를 이용하여 수행하였고, $94{ }^{\circ} \mathrm{C}$ 에서 2분간 $\mathrm{DNA}$ 를 변성시키고, $94{ }^{\circ} \mathrm{C}-1$ 분, $55{ }^{\circ} \mathrm{C}-1$ 분, $72{ }^{\circ} \mathrm{C}$ - 90초로 이루어진 합성반응을 30회 반복한 후, $72{ }^{\circ} \mathrm{C}$ 에서 10 분간 최종 신장하고 $4{ }^{\circ} \mathrm{C}$ 에서 보 관하였다. PCR 산물은 $1 \%$ agarose gel 상에서 전 기영동 확인하였고, Agarose Gel DNA Extraction Kit(Roche, Germany)로 정제하여 cloning에 이 용하였다.

\section{3. 집단유전학적 분석}

다형성을 나타내는 염기서열에 대한 Duroc 품종 집단 내 유전적 다양성을 조사하기 위하 여 mtDNA D-loop과 ND2 유전자, $C Y T B$ 유전 자에 대한 PCR-RFLP 분석을 수행하였다. 각각 의 유전자를 증폭하기 위해 specific primer set 을 고안하였다.

D-loop duplication motif:

D-DuF 5'-CAT TTA ACA ACA CAA ACC ACC A-3'

D-DUR 5'-GAT TGG CGT AAA AAT CTA GGG-3'

CYTB :

bCYBF 5'-TCG TTG TCA TTC AAC TAC AAG AAC-3'

bCYBR 5'-CCT TCT CTG GTT TAC AAG ACC A-3'

ND2:

5008F 5'-ACA TTC TAC AGT AAG GTC AG-3'

5245R 5'-TGT GGC TCG TGG GTT AAA AT-3'

PCR 증폭은 각각의 primer set의 적정 결합 온도를 채택하고 조 등(2003)의 방법을 변형하 여 수행하였다. D-loop duplication motif의 분석 은 증폭한 PCR 산물을 polyacrylamide gel 전기 영동(PAGE)법으로 확인하였다. ND2 개시코돈 에 대한 다형성은 Tsp509। 제한효소 처리 후 $4 \%$ agarose gel 상에서 전기영동 확인하고, 발 견된 양상에 따라 DNA 염기서열 분석으로 확 인하였다. CYTB 유전자에 대한 분석은 제한효
소 Alu I 과 Haell| RFLP를 수행하였다. 제한효 소의 처리는 공급자의 manual에 따라 최적온도 에서 overnight 반응하였고, 절편 양상은 PAGE 법으로 확인하였다. 조사에 이용된 모든 개체 들에서 발견된 ND2, CYTB 유전자의 RFLP 유 형들과 D-loop의 duplication 출현 여부를 조합 하여 mtDNA haplotype을 결정하였다.

\section{4. 유전자 Cloning과 염기서열 분석}

돼지 Duroc의 mtDNA 전체 서열 결정과 집 단 내 다형현상을 나타내는 유전자 서열의 확인을 위하여 DNA sequencing을 수행하였 다. 정제된 PCR 산물은 TOPO TA Cloning Kit (Invitrogen, USA)으로 cloning한 후, Wizard Plus SV Minipreps(Promega, USA)으로 plasmid $\mathrm{DNA}$ 를 추출하였다. 추출한 plasmid를 주형으 로 sequencing 반응 후 ABI PRISM 3730 DNA Sequencer(Perkin Elmer, USA)를 이용하여 실시 하였다. 결정된 염기서열은 Ursing과 Arnason (1998), Lin 등(1999)에 의해 보고된 돼지 mtDNA 전체 서열(GenBank accession No. NC_000845) 과 비교하여 유전자 경계 등 특성을 확인하였 다. 유전자 서열에 대한 아미노산 서열로의 변 환은 $\mathrm{NCBI}$ 에서 제공되는 ORFfinder web program을 이용하였다. 본 연구에서 결정된 Duroc 품종 mtDNA 전체 염기서열과 아미노산서열은 GenBank database에 accession No. AY337045로 등록되어 있다.

\section{5. 계통유전학적 분석}

본 연구에서 결정된 Duroc 품종 mtDNA 서 열(Duroc2)의 계통유전학적 분석을 위해 Yang 등(2003)에 의해 보고된 Duroc 서열(Duroc1)과 야생멧돼지 2서열(Italian wild boar, Swedish wild boar), Landrace 2서열, Large White 1 서 열, 중국재래돼지 17품종 등 총 24서열들을 비 교분석하였다(Lin 등, 1999; Kijas와 Andersson, 2001; Yang 등, 2003). 서열 중 tandem repeat heteroplasmy를 보이는 D-loop의 일부를 제외한 거의 전체 $\mathrm{mtDNA}$ 서열(15,976-bp)을 비교하였 
으며, 염기서열을 다중 정렬한 후 유전적 거리 지수를 산출하고 이를 근거로 계통수를 작성하 였다. CLUSTAL W(Thompson 등, 1994) program으로 다중정렬한 후, PHYLIP program package(Felsenstein, 1993)의 DNADIST의 two parameter method(Kimura, 1980)에 따라 염기서 열 간 유전적 거리지수를 산출하였다. 유전적 거리지수를 토대로 neighbor-joining(NJ) method(Saitou and Nei, 1987)를 이용하여 계통수를 작성하였다.

\section{III 결과 및 고찰}

돼지 Duroc 품종의 미토콘드리아 유전체의 전체 서열을 결정하기 위하여 $\operatorname{Lin}$ 등(1999)에 의해 보고된 돼지 mtDNA 서열을 기준으로 primer를 제작하였고 14절편의 PCR 산물로 증 폭하여 염기서열을 결정하였다(Fig. 1). 각각의 절편들에서 결정된 염기서열들을 기존에 Ursing 과 Arnason(1998), Lin 등(1999)에 의해 보고된 서열과 비교하여 $\mathrm{mtDNA}$ 내에 암호화되어 있는 구조유전자(rRNA, tRNA, peptide coding gene)들 과 D-loop의 경계와 길이를 확인하였다.

돼지 Duroc 품종의 mtDNA 서열은 2종류의 $\operatorname{rRNA}(12 \mathrm{~S}$ 와 $16 \mathrm{~S})$ 와 22종류의 tRNA, 13종류의 미토콘드리아 peptide 암호화 유전자들과 조절 영역인 D-loop으로 구성되어 있었으며, 암호화 된 유전자의 순서와 길이 역시 기존의 보고들 과 유사한 결과를 보였다. 본 연구에서 결정된 Duroc 품종의 mtDNA 서열의 길이는 $16,584-b p$ 이며, peptide 암호화 부위에는 길이의 차이를 나타낼 수 있는 삽입/결실 현상이 나타나지 않 았으나 D-loop과 tRNA, rRNA 유전자 영역에서
는 삽입/결실이 관찰되었다. 대부분의 peptide coding gene들과 구조 RNA 유전자들은 H-strand 에, ND6와 8종류의 tRNA 유전자들은 L-strand 상에 암호화되어 있었다. mtDNA 서열 길이의 다양성을 나타내는 주된 요인으로 알려져 있는 10-bp tandem repeat(TACACGTGCG)가 D-loop 내에서 10 회 반복되어 출현하였다. 또한 대부 분의 포유동물의 미토콘드리아 유전체의 tRNAAsn과 tRNA-Cys 사이에 L-가닥 복제분기점 (light-strand replication origin; OL)이 존재하며 고도로 보존된 서열로 알려져 있다. 돼지에서 OL 서열은 야생멧돼지를 포함한 돼지 24서열 에서 보고되었으나, 염기서열의 변이는 없었다 (Ursing과 Arnason, 1998; Lin 등 1999; Kijas와 Andersson, 2001; Yang 등, 2003). OL 영역의 특징은 서열의 중간에 13 개의 염기를 중심으로 양쪽에 상보적으로 11 개의 염기가 좌우대칭인 구조가 hairpin stem-loop를 형성한다. 또한 $\mathrm{OL}$ 영역은 포유류 외에도 어류 등에서도 관찰이 되었는데(Lee 등, 2001), 포유류와 같은 위치에 서 관찰되었으나, 염기서열과 길이에서 차이가 있는 것으로 확인되었다.

Table 1은 Duroc 품종의 mtDNA 전체서열 상에서 나타나는 모든 유전자의 길이와 서열상 의 위치, 핵 DNA에서 나타나는 유전암호와 구 분되는 개시코돈과 종결코돈의 서열 등을 나타 낸 것이다. 13 종류의 peptide 유전자들 중에서 $A T P 8$ 과 ATP6, $N D 4 L$ 과 $N D 4, N D 5$ 와 $N D 6$ 은 염 기서열의 일부가 서로 중첩되어 있었고, 몇몇 peptide 유전자들 $(C O / /, C O / / /, N D 3, N D 4)$ 은 불완전한 종결코돈을 나타내었다(Table 1). 미 토콘드리아 유전체의 peptide 유전자에서 불완 전한 종결코돈 $\mathrm{T}-$-로 나타내며, 이들은 전사-

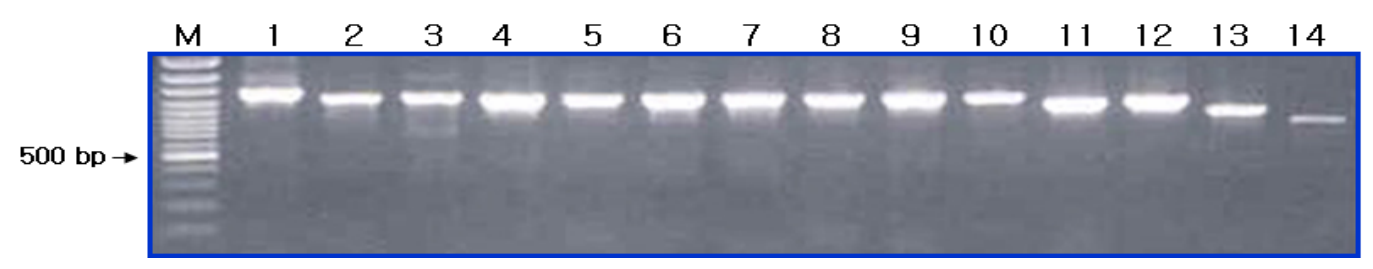

Fig. 1. PCR amplification of porcine mtDNA with fourteen primer sets. $M$ is the DNA size marker 100-bp DNA ladder. 
Table 1. Characteristics of the complete mitochondrial DNA sequences of Duroc breed

\begin{tabular}{|c|c|c|c|c|c|}
\hline \multirow{2}{*}{ Gene } & \multicolumn{2}{|c|}{ Position } & \multirow{2}{*}{$\begin{array}{l}\text { Size } \\
\text { (bp) }\end{array}$} & \multicolumn{2}{|c|}{ Codon } \\
\hline & From & To & & initiation & termination \\
\hline D-loop & 1 & 1,145 & 1,145 & & \\
\hline CSB-1 & 675 & 700 & & & \\
\hline CSB-2 & 844 & 862 & & & \\
\hline CSB-3 & 895 & 913 & & & \\
\hline tRNA-Phe & 1,146 & 1,215 & 70 & & \\
\hline 12S rRNA & 1,216 & 2,177 & 962 & & \\
\hline tRNA-Val & 2,178 & 2,245 & 68 & & \\
\hline 16S rRNA & 2,246 & 3,814 & 1,569 & & \\
\hline tRNA-Leu(UUR) & 3,815 & 3,889 & 75 & & \\
\hline NADH dehydrogenase subunit 1(ND1) & 3,892 & 4,848 & 957 & ATG & TAG \\
\hline tRNA-Ile & 4,847 & 4,915 & 69 & & \\
\hline tRNA-Gln & 4,913 & 4,985 & 73 & & \\
\hline tRNA-Met & 4,987 & 5,056 & 70 & & \\
\hline NADH dehydrogenase subunit 2(ND2) & 5,057 & 6,100 & 1,044 & ATT & TAG \\
\hline tRNA-Trp & 6,099 & 6,166 & 68 & & \\
\hline tRNA-Ala & 6,173 & 6,240 & 68 & & \\
\hline tRNA-Asn & 6,242 & 6,316 & 75 & & \\
\hline tRNA-Cys & 6,349 & 6,414 & 66 & & \\
\hline tRNA-Tyr & 6,414 & 6,479 & 66 & & \\
\hline Cytochrome c oxidase subunit $\mathrm{I}(\mathrm{COI})$ & 6,481 & 8,025 & 1,545 & ATG & TAA \\
\hline tRNA-Ser(UCN) & 8,029 & 8,099 & 71 & & \\
\hline tRNA-Asp & 8,105 & 8,172 & 68 & & \\
\hline Cytochrome c oxidase subunit II(COII) & 8,173 & 8,859 & 687 & ATG & T-- \\
\hline tRNA-Lys & 8,861 & 8,927 & 67 & & \\
\hline ATP subunit 8(ATP8) & 8,929 & 9,132 & 204 & ATG & TAA \\
\hline ATP subunit 6(ATP6) & 9,090 & 9,770 & 681 & ATG & TAA \\
\hline Cytochrome c oxidase subunit III(COIII) & 9,770 & 10,552 & 783 & ATG & T-- \\
\hline tRNA-Gly & 10,554 & 10,622 & 69 & & \\
\hline NADH dehydrogenase subunit 3(ND3) & 10,623 & 10,967 & 345 & ATA & T-- \\
\hline tRNA-Arg & 10,967 & 11,038 & 72 & & \\
\hline NADH dehydrogenase subunit $4 \mathrm{~L}(N D 4 L)$ & 11,039 & 11,335 & 297 & GTG & TAA \\
\hline NADH dehydrogenase subunit 4(ND4) & 11,329 & 12,705 & 1,377 & ATG & T-- \\
\hline tRNA-His & 12,707 & 12,775 & 69 & & \\
\hline tRNA-Ser(AGY) & 12,776 & 12,834 & 59 & & \\
\hline tRNA-Leu(CUN) & 12,835 & 12,904 & 70 & & \\
\hline NADH dehydrogenase subunit 5(ND5) & 12,905 & 14,728 & 1,824 & ATA & TAA \\
\hline NADH dehydrogenase subunit $6(N D 6)$ & 14,712 & 15,239 & 528 & ATG & TAA \\
\hline tRNA-Glu & 15,240 & 15,308 & 69 & & \\
\hline Cytochrome b(CYTB) & 15,313 & 16,452 & 1,140 & ATG & AGA \\
\hline tRNA-Thr & 16,453 & 16,520 & 68 & & \\
\hline tRNA-Pro & 16,521 & 16,584 & 64 & & \\
\hline
\end{tabular}


해독 과정에서 $\operatorname{poly}(\mathrm{A})$ tailing 과정 중 아데닌 염기 부착으로 종결코돈이 완전해지는 것으로 알려져 있다. 핵 DNA에 암호화된 단백질 유전 자의 경우는 개시코돈 ATG가 공통으로 알려져 있으나, 포유류 mtDNA의 몇몇 peptide 유전자 에서 ATG 외에도 ATA, ATT, GTG, ATC 등의 개시코돈들도 보고되었다(Arnason 등, 1993; Lopez 등, 1996; Kijas와 Andersson, 2001; Janke 등, 2002; Coble 등, 2004). 돼지에서 ATG와 ATT, ATA, GTG 등이 보고되었고 본 연구에 서 결정된 염기서열에서도 동일한 양상을 보이 고 있었다(Table 1).

계통수 상에서 24서열의 돼지 mtDNA 서열 들은 아시아와 유럽 계열로 크게 양분되었다 (Fig. 3). 유럽 계열의 개체 간 유전적 거리지수 는 $0.0044 \pm 0.0033$ 으로 아시아 계열 $(0.0007 \pm$ 0.0003)보다 높았고, 이는 유럽돼지 집단이 아
시아 돼지 집단보다 유전적 다양성이 훨씬 높 다는 것을 보여주는 결과이며 앞선 연구결과들 과 동일한 양상이다. 유럽돼지 집단 내에서의 유전적 거리지수를 살펴보면, Duroc1-Landrace1 이 가장 낮고, Duroc 품종 두 서열 간 거리지 수는 Duroc-Landrace, Duroc-Swedish wild boar 의 거리지수보다도 높았고 Duroc-Italian wild boar보다는 낮았다(Table 2). 이 결과는 Duroc 품종 내에서의 mtDNA 염기 변이가 Landrace나 Swedish wild boar와의 염기변이보다 훨씬 많다 는 것으로, Duroc1과 Duroc2의 모계가 서로 다 른 기원에서 유래되었음을 시사한다. 유럽계열 중에서 Swedish wild boar가 Duroc뿐만 아니라 Landrace와 근연의 관계인 것으로 보아 이들 품종의 모계는 아마도 북유럽의 야생멧돼지에 서 기원했을 것으로 추정된다. 또한 이들 두 품종의 가축화 과정이나 품종 형성 이전에 동

Table 2. Genetic distances among $24 \mathrm{mtDNA}$ sequences of various pig breeds

\begin{tabular}{|c|c|c|c|c|c|c|c|c|c|c|c|c|c|c|c|c|c|c|c|c|c|c|c|c|}
\hline & 1 & 2 & 3 & 4 & 5 & 6 & 7 & 8 & 9 & 10 & 11 & 12 & 13 & 14 & 15 & 16 & 17 & 18 & 19 & 20 & 21 & 22 & 23 & 24 \\
\hline 1 Landrace1 & - & & & & & & & & & & & & & & & & & & & & & & & \\
\hline 2 Swedish wild boar & 0.0011 & - & & & & & & & & & & & & & & & & & & & & & & \\
\hline 3 Landrace2 & 0.0019 & 0.0024 & - & & & & & & & & & & & & & & & & & & & & & \\
\hline 4 Duroc1 & 0.0007 & 0.0012 & 0.0020 & - & & & & & & & & & & & & & & & & & & & & \\
\hline 5 Duroc2 & 0.0029 & 0.0034 & 0.0039 & 0.0030 & - & & & & & & & & & & & & & & & & & & & \\
\hline 6 Italian wild boar & 0.0084 & 0.0084 & 0.0094 & 0.0082 & 0.0096 & - & & & & & & & & & & & & & & & & & & \\
\hline 7 Dahuabai & 0.0120 & 0.0124 & 0.0131 & 0.0117 & 0.0117 & 0.0113 & - & & & & & & & & & & & & & & & & & \\
\hline 8 Ningxiang & 0.0118 & 0.0122 & 0.0129 & 0.0115 & 0.0115 & 0.0112 & 0.0003 & - & & & & & & & & & & & & & & & & \\
\hline 9 Erhualian & 0.0120 & 0.0124 & 0.0131 & 0.0117 & 0.0116 & 0.0112 & 0.0007 & 0.0005 & - & & & & & & & & & & & & & & & \\
\hline 10 Zang & 0.0122 & 0.0125 & 0.0132 & 0.0117 & 0.0118 & 0.0116 & 0.0011 & 0.0009 & 0.0011 & - & & & & & & & & & & & & & & \\
\hline 11 Jiangquhai & 0.0118 & 0.0122 & 0.0129 & 0.0115 & 0.0114 & 0.0111 & 0.0009 & 0.0007 & 0.0008 & 0.0010 & - & & & & & & & & & & & & & \\
\hline 12 Meishan & 0.0120 & 0.0124 & 0.0131 & 0.0117 & 0.0116 & 0.0113 & 0.0011 & 0.0009 & 0.0010 & 0.0012 & 0.0002 & - & & & & & & & & & & & & \\
\hline 13 W annanhua & 0.0118 & 0.0122 & 0.0129 & 0.0114 & 0.0115 & 0.0110 & 0.0008 & 0.0006 & 0.0008 & 0.0011 & 0.0002 & 0.0004 & - & & & & & & & & & & & \\
\hline 14 Large White & 0.0118 & 0.0122 & 0.0129 & 0.0115 & 0.0115 & 0.0113 & 0.0011 & 0.0009 & 0.0010 & 0.0012 & 0.0003 & 0.0005 & 0.0004 & - & & & & & & & & & & \\
\hline 15 Jinhua & 0.0117 & 0.0121 & 0.0128 & 0.0114 & 0.0113 & 0.0110 & 0.0009 & 0.0008 & 0.0009 & 0.0011 & 0.0002 & 0.0004 & 0.0003 & 0.0004 & $4-$ & & & & & & & & & \\
\hline 16 Qingping & 0.0121 & 0.0125 & 0.0132 & 0.0118 & 0.0117 & 0.0114 & 0.0013 & 0.0011 & 0.0013 & 0.0014 & 0.0006 & 0.0006 & 0.0006 & 0.0008 & 80.0005 & - & & & & & & & & \\
\hline 17 Tongcheng & 0.0120 & 0.0124 & 0.0131 & 0.0117 & 0.0116 & 0.0113 & 0.0011 & 0.0009 & 0.0010 & 0.0012 & 0.0003 & 0.0005 & 0.0004 & 0.0005 & 50.0004 & 0.0003 & - & & & & & & & \\
\hline 18 Yushanhei & 0.0120 & 0.0124 & 0.0131 & 0.0117 & 0.0116 & 0.0113 & 0.0011 & 0.0009 & 0.0010 & 0.0012 & 0.0004 & 0.0006 & 0.0005 & 0.0006 & 60.0005 & 0.0004 & 0.0001 & - & & & & & & \\
\hline 19 Min & 0.0120 & 0.0124 & 0.0131 & 0.0117 & 0.0117 & 0.0113 & 0.0011 & 0.0009 & 0.0011 & 0.0013 & 0.0004 & 0.0006 & 0.0004 & 0.0006 & 60.0004 & 0.0008 & 0.0006 & 0.0007 & - & & & & & \\
\hline 20 Rongchang & 0.0117 & 0.0121 & 0.0128 & 0.0114 & 0.0113 & 0.0112 & 0.0007 & 0.0005 & 0.0006 & 0.0008 & 0.0002 & 0.0004 & 0.0003 & 0.0004 & 40.0003 & 0.0006 & 0.0004 & 0.0005 & 0.0004 & - & & & & \\
\hline 21 Xiang & 0.0118 & 0.0122 & 0.0129 & 0.0115 & 0.0115 & 0.0113 & 0.0008 & 0.0006 & 0.0008 & 0.0009 & 0.0004 & 0.0006 & 0.0005 & 0.0006 & 60.0005 & 0.0009 & 0.0006 & 0.0008 & 0.00070 & 0.0003 & - & & & \\
\hline 22 Yimenghei & 0.0122 & 0.0125 & 0.0132 & 0.0118 & 0.0118 & 0.0113 & 0.0011 & 0.0009 & 0.0008 & 0.0013 & 0.0008 & 0.0009 & 0.0008 & 0.0009 & 90.0008 & 0.0012 & 0.0009 & 0.0009 & 0.00100 & 0.0007 & 0.0008 & - & & \\
\hline 23 Wuzhishan & 0.0118 & 0.0122 & 0.0129 & 0.0115 & 0.0115 & 0.0112 & 0.0008 & 0.0006 & 0.0006 & 0.0009 & 0.0007 & 0.0009 & 0.0008 & 0.0009 & 90.0008 & 0.0011 & 0.00090 & 0.0009 & 0.00090 & 0.00050 & 0.0006 & 0.0008 & - & \\
\hline 24 Short-ear & 0.0124 & 0.0127 & 0.0134 & 0.0120 & 0.0120 & 0.0116 & 0.0019 & 0.0017 & 0.0017 & 0.0021 & 0.0016 & 0.0018 & 0.0016 & 0.0018 & 80.0017 & 0.0021 & 0.0018 & 0.0018 & 0.00190 & 0.0016 & 0.0017 & 0.00200 & 0.0018 & - \\
\hline
\end{tabular}
IWB, Italian wild boar; SWB, Swedish wild boar. 
일한 모계선조에서 유래했을 가능성이 높다고 사료된다.

Duroc 품종 집단에 대한 유전학적 분석은 모 계가 단일기원이 아닐 가능성을 재확인시켜 주 고 있다. mtDNA D-loop 영역에서 조 등(2003) 에 의해 발견된 11-bp duplication 양상과 $N D 2$ 유전자 개시코돈의 다형성, $C Y T B$ 유전자에 대 한 분석 결과에서 mtDNA 전체 서열에 대한 계통분석을 뒷받침하는 증거들을 찾을 수 있었 다. 먼저, D-loop에서 11-bp duplication motif는 총 125 두 중에서 19 두(15.2\%)에서 관찰되었다. 반면, Large White는 조사한 개체 모두에서 $\mathrm{du}-$ plication motif가 관찰되었고 Landrace 집단에서 는 전혀 관찰되지 않았다(Fig. 2A). ND2 유전 자의 개시코돈 서열에 대한 분석에서 선택적 개시코돈(AIC)이 발견되었고, 조사한 세 품종 집단에서 서로 다른 빈도를 나타내었다. Duroc 은 ATA와 ATT 두 가지 서열을 모두 갖지만, Large White는 ATA, Landrace는 ATT만인 것으 로 확인되었다(Fig. 2B). Yang 등(2003)은 중국 재래돼지 17 품종에서 $N D 2$ 유전자의 개시코돈 은 모두 ATA이고, Landrace와 Duroc은 ATT, Large White는 ATA로 보고하였고, Lin 등

D-loop 11-bp duplication

M1 D1 D2 LR LW

$\mathbf{A}$

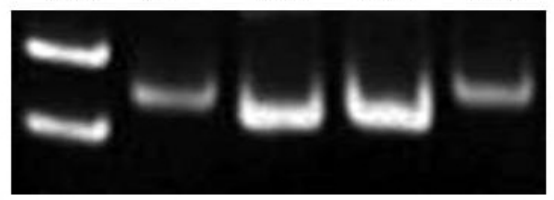

$A l u$ I - RFLP of $C Y T B$

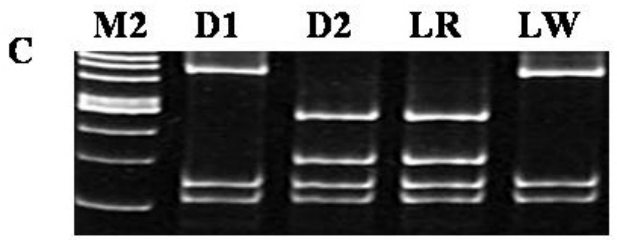

(1999)의 보고에서 Landrace는 ATT 서열을 나 타내었다(Table 2). mtDNA 전체 서열이 보고된 모든 돼지 품종에서 ND2 유전자 개시코돈을 확인한 결과, Italian wild boar를 제외한 유럽계 열들에서 ATT, 아시아 돼지들은 모두 ATA 서 열을 보였다. CYTB 유전자에 대한 RFLP 분석 에서 Alu I 과 Haelll 다형성은 개체들 사이에 서 완전히 연관된 양상으로 관찰되었고(Fig. 2C 와 $\mathrm{D})$, 이들 다형성은 $\mathrm{ND} 2$ 개시코돈의 $\mathrm{AIC}$, D- loop에서 11-bp duplication의 출현과도 동일 한 양상을 나타내었다. Table 3은 돼지 품종 집 단들에서 다형성 양상을 정리하여 mtDNA haplotype을 결정한 결과이다.

세 품종의 돼지 집단들은 두 가지 hapotype 들로 구분되었다. Large White 집단은 $m t Y D$, Landrace 집단은 $m t L D$ 만을 나타내고, Duroc 집 단은 두 가지 haplotype들이 모두 출현하였다 (Table 2). 집단에 대한 mtDNA haplotype의 분 석 결과와 돼지 mtDNA 서열에 대한 계통분석 결과를 비교해 보면, 유럽과 아시아 계열의 돼 지 품종들이 분지되는 양상과 haplotype에 의해 구분되는 양상이 동일함을 알 수 있었다. 이는 본 연구에서 분석한 mtDNA haplotype이 어느

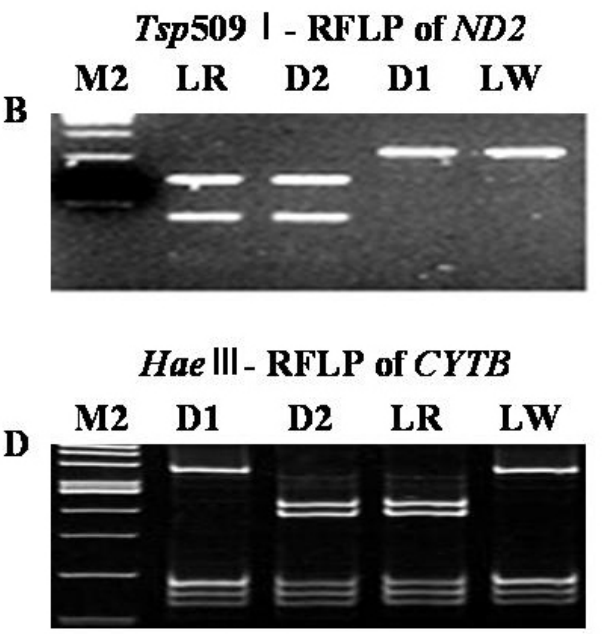

Fig. 2. Detection of mtDNA polymorphism from pig breeds Duroc, Landrace and Large White. A, 11-bp duplication patterns; B, Tsp509 I 2FLP of ND2 gene; C and D, RFLP of CYTB gene using by $A l u \mathrm{I}$ and Haell respectively. D, Duroc; LR, Landrace; LW, Large White. M1 and M2 are the DNA size markers 50-bp and 100-bp DNA ladder, respectively. 
Table 3. mtDNA haplotypes found in pig breeds determined in this study

\begin{tabular}{|c|c|c|c|c|c|c|c|c|c|}
\hline \multirow{2}{*}{ Haplotype } & \multicolumn{3}{|c|}{ Gene } & \multicolumn{2}{|c|}{ Duroc } & \multicolumn{2}{|c|}{ Landrace } & \multicolumn{2}{|c|}{ Large White } \\
\hline & D-loop & $N D 2^{1)}$ & $\mathrm{CYTB}^{2)}$ & $\mathrm{n}$ & $\%$ & $\mathrm{n}$ & $\%$ & $\mathrm{n}$ & $\%$ \\
\hline mtYD & Duplicated & ATA & $A A-H A$ & 19 & 15.2 & 0 & 0.0 & 76 & 100 \\
\hline mtLD & Non-duplicated & ATT & $A B-H B$ & 106 & 84.8 & 40 & 100 & 0 & 0.0 \\
\hline
\end{tabular}

1) is the sequence of the initiation condon of mitochondrial ND2 gene.

2) enzyme morphs digested with $\mathrm{Alu}$ I (AA, AB) and Hae III (HA, HB), respectively.

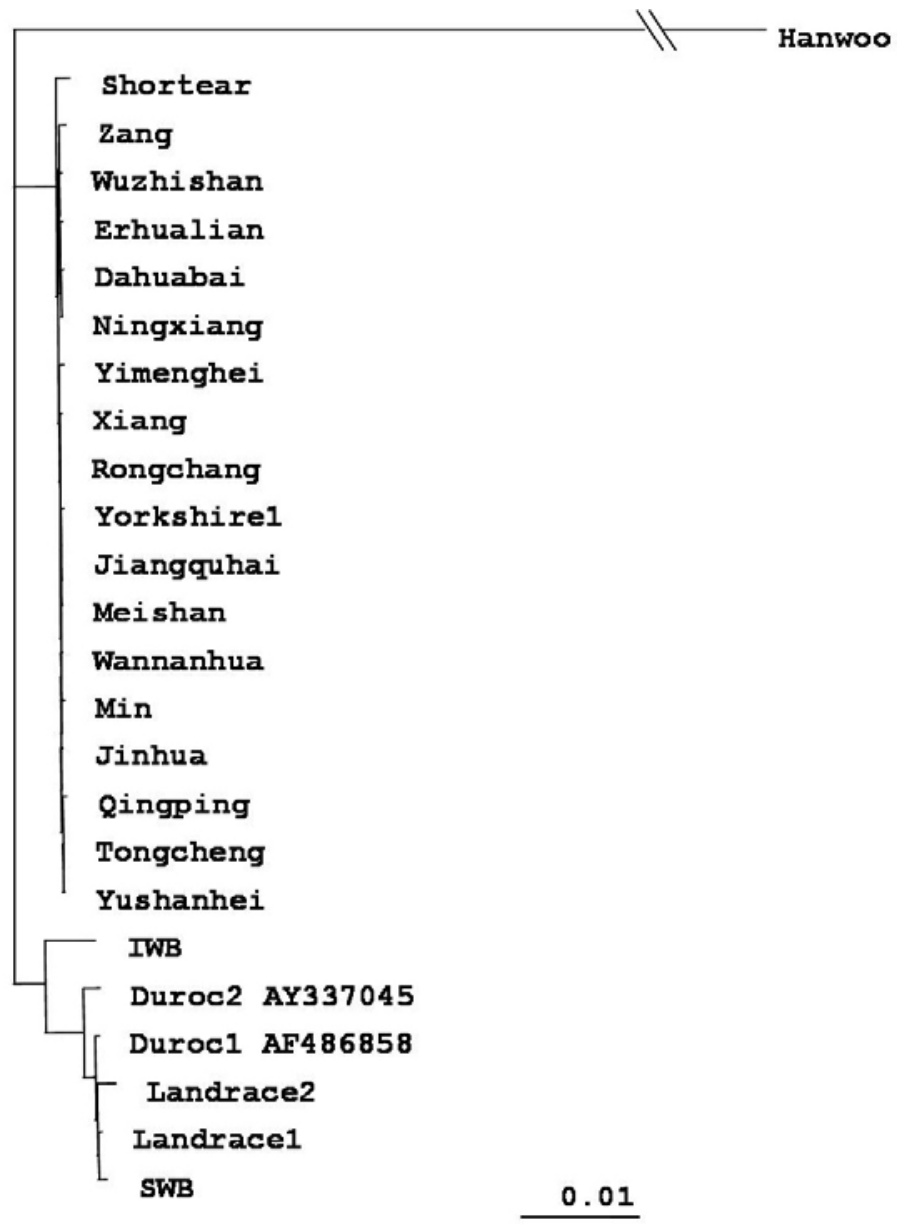

Fig. 3. Neighbor-joining tree based on genetic distances calculated from nucleotide similarity. Number above bar indicates genetic distance.

\begin{abstract}
정도 유럽과 아시아 계통을 대표할 수 있는 염 기서열의 다형성을 내포하고 있기 때문으로 사 료된다. 또한 이러한 결과는 이들 품종들의 품 종형성과정에서 관여했을 모계선조 집단의 기 원을 추정할 수 있는 자료가 될 것으로 보인 다. Landrace와 Duroc, Large White 세 품종 모

두 품종 형성의 초기 단계에서 유럽계열의 야 생멧돼지를 가축화한데서 유래되었으며, 18세 기 이후 아시아와의 교역을 통하여 아시아산 돼지 품종들을 도입하여 품종개량에 이용하였 으며, 최근의 연구들은 아시아계열의 돼지를 모계로 이용했다는 분자유전학적 증거들이 밝
\end{abstract}


혀지고 있다(Watanabe 등, 1985; Jones, 1998; Giuffra 등, 2000; Okumura 등, 2001; Alves 등, 2003).

이상의 결과를 종합해 보면, 2가지 mtDNA haplotype들을 보이는 Duroc 품종은 적어도 둘 이상의 모계선조에서부터 유래한 것으로 사료 된다. 또한 현재까지 정확한 경로를 추정할만 한 자료는 없지만 품종 형성 이전 단계에서 Landrace와 Duroc이 동일한 모계선조에서 기원 했을 가능성은 대단히 높은 반면, Duroc 품종 의 일부는 이후 유입된 아시아 계열 돼지를 모 계로 이용하였다고 사료된다. 본 연구 결과는 Duroc 품종 형성과정을 이해하는 데 중요한 자 료가 될 것이다. 앞으로 전 세계에서 사육되고 있는 다수의 Duroc 집단뿐만 아니라 이들의 선 조로 추정되는 다른 품종에 대한 mtDNA 서열 과 핵 DNA 유전자들을 대상으로 비교연구가 수행된다면, 아직까지 밝혀지지 않은 품종 형 성과정을 이해하는데 보다 나은 결과를 산출해 낼 수 있을 것으로 사료된다.

\section{IV 요 약}

Duroc 품종은 돼지 사육에 있어 산육성과 육 질 향상을 위해 이용되고 있다. 본 연구는 육 종에 많이 이용되는 Duroc 품종의 모계 특이적 인 서열의 검색과 계통유전학적 유연관계의 정 립을 위하여 미토콘드리아 유전체의 전체 염기 서열을 결정하고 집단 내 다형성을 조사하였 다. mtDNA 전체 서열의 길이는 $16,584-\mathrm{bp}$ 이 고, D-loop과 tRNA, rRNA 유전자 영역에서는 삽입/결실이 확인되었다. 4개의 coding gene (CO //, CO///, ND3, ND4)에서 불완전한 종결 코돈을, $N D 4 L$ 과 $N D 2$ 유전자는 선택적 개시코 돈 양상을 보였다. Duroc 집단에 대한 분석 결 과 조절영역에서의 특이적인 11-bp 중복 단위 가 일부 개체(15.2\%)에서 발견되었고, ND2의 개시코돈과 $C Y T B$ 유전자에서도 다형현상을 보 였다. 각각의 유전자 영역에서의 다형성은 서 로 연관되어 있었고, 그 결과 Duroc 집단은 크 게 두 가지 haplotype으로 구분되었다. 계통수 에서 Duroc mtDNA 서열은 유럽계열 cluster에
위치하였으나, haplotype 분석과 기존에 연구결 과들을 종합해 보면 Duroc 품종은 여러 모계선 조 집단에서 기원한 것으로 보이며, 유럽과 아 시아 계열 모두가 품종 형성에 이용된 것으로 사료된다.

\section{$\mathrm{V}$ 인 용 문 헌}

1. Alves, E., Ovilo, C., Rodriguez, M. C. and Silio, L. 2003. Mitochondrial DNA sequence variation and phylogenetic relationships among Iberian pigs and other domestic and wild pig populations. Anim. Genet. 34:319-324.

2. Anderson S., Bankier, A. T., Barrell, B. G., Bruijin, M. H. L., Coulson, A. R., Drouin, J., Eperon, I. C., Nierlich, C. D., Roe, B. A., Sanger, F., Schreier, P. H., Smith, A. J., Staden, R. and Young, I. G. 1981. Sequence and organization of the human mitochondrial genome. Nature 290: 457-465.

3. Arnason, U. and Gullberg, A. 1993. Comparison between the complete mtDNA sequences of the blue and the fin whale, two species that can hybridize in nature. J. Mol. Evol. 37:312-322.

4. Birren, B., Green, E. D., Klapholz, S., Myers, R. M. and Roskams, J. 1997. Genome analysis: A laboratory manual. Cold Spring Harbor Laboratory Press, USA.

5. Bökönyi, S. 1974. History of domestic mammals in central and eastern Europe. Academiai Kiado, Budapest.

6. Brown, W. M., George, M. and Wilson, A. C. 1979. Rapid evolution of animal mitocondrial DNA. Proc. Natl. Acad. Sci. U.S.A. 76:1967-1971.

7. Cann, R. L., Brown, W. M. and Wilson, A. C. 1984. Polymorphic sites and the mechanism of evolution in human mitochondrial DNA. Genetics 325:31-36.

8. Coble, M. D., Just, R. S., O'Callaghan, J. E., Letmanyi, I. H., Peterson, C. T., Irwin, J. A. and Parsons, T. J. 2004. Single nucleotide polymorphisms over the entire mtDNA genome that increase the power of forensic testing in Caucasians. Int. J. Legal. Med. In press.

9. Felsenstein, J. 1993. PHYLIP(Phylogeny Inference Package) ver. 3.572, Computer program distributed by the author, Dept. of Genetics, University of Washington, Seattle, WA.

10. Giles, R. E., Blanc, H., Cann, H. M. and Wallace, D. C. 1980. Maternal inheritance of hu- 
man mitochondrial DNA. Proc. Natl. Acad. Sci. U.S.A. 77:6715-6719.

11. Giuffra, E., Kijas, J. M. H., Amarger, V., Carlborg, O., Jeon, J. T. and Andersson, L. 2000. The origin of the domestic pig: independent domestication and subsequent introgression. Genetics 154:1785-1791.

12. Janke, A., Magnell, O., Wieczorek, G., Westerman, M. and Arnason, U. 2002. Phylogenetic analysis of 18S rRNA and the mitochondrial genomes of the wombat, Vombatus ursinus, and the spiny anteater, Tachyglossus aculeatus: increased support for the Marsupionta hypothesis J. Mol. Evol. 54:71-80.

13. Jones, G. F. 1998. Genetic aspects of domestication, common breeds and their origin, pp. 17-50 in The Genetics of the Pig, edited by A. Ruvinsky and M. F. Rothschild. CAB International, Oxon, UK.

14. Kijas, J. M. H. and Andersson, L. 2001. A phylogenetic study of the domestic pig estimated from the near-complete mtDNA genome. J. Mol. Evol. 52:302-308.

15. Kijas, J. M. H., Moller, M., Plastow, G. and Andersson, L. 2001. A frameshift mutation in $M C 1 R$ and a high frequency of somatic reversions cause black spotting in pigs. Genetics 158:779785 .

16. Kijas, J. M. H., Wales, R., Tornsten, A., Chardon, P., Moller, M. and Andersson, L. 1998. Melanocortin receptor $1(M C 1 R)$ mutations and coat color in pigs. Genetics 150:1177-1185.

17. Kim, K. I., Lee, J. H., Li, K., Zhang, Y. P., Lee, S. S., Gongora, J. and Moran, C. 2002. Phylogenetic relationships of Asian and European pig breeds determined by mitochondrial DNA D-loop sequence polymorphism. Anim. Genet. 33:19-25.

18. Kimura, M. 1980. A simple method for estimating evolutionary rates of base substitutions through comparable studies of nucleotide sequences. J. Mol. Evol. 16:111-120.

19. Lee, J. S., Miya, M., Lee, Y. S., Kim, C. G., Park, E. H., Aoki, Y. and Nishida, M. 2001. The complete DNA sequence of the mitochondrial genome of the self-fertilizing fish Rivulus marmoratus(Cyprinodontiformes, Rivulidae) and the first finding of duplication of control region in fish. Gene 280:1-7.

20. Lin, C. S., Sun, Y. L. and Liu, C. Y. 1999. Complete nucleotide sequence of pig(Sus scrofa) mitochondrial genome and dating evolutionary divergence within Artiodactyla. Gene 236:107-114.
21. Lopez, J. V., Cevario, S. and O'Brien, S. J. 1996. Complete nucleotide sequences of the domestic cat(Felis catus) mitochondrial genome and a transposed mtDNA tandem repeat(Numt) in the nuclear genome. Genomics 33:229-246.

22. Okumura, N., Ishiguro, N., Nakano, M., Katsuya, H., Matsui, A. and Sahara, M. 1996. Geographic population structure and sequence divergence in the mitochondrial DNA control region of the Japanese wild boar(Sus scrofa leucomystax), with reference to those of domestic pigs. Biochem. Genet. 34:179-189.

23. Saitou, N. and Nei, M. 1987. The neighbor-joining method: A new method for reconstructing phylogenetic trees. Mol. Biol. Evol. 4:406-425.

24. Thompson, J. D., Higgins, D. G. and Gibson, T. J. 1994. CLUSTAL W: improving the sensitivity of progressive multiple sequence alignment through sequence weighting position specific gap penalties and weight matrix choice. Nucl. Acids Res. 22:4673-4680.

25. Ursing, B. M. and Arnason, U. 1998. The complete mitochondrial DNA sequence of the pig(Sus scrofa). J. Mol. Evol. 47:302-306.

26. Watanabe, T., Hayashi, Y., Ogasawara, N. and Tomita, T. 1985. Polymorphism of mitochondrial DNA in pigs based on restriction endonuclease cleavage patterns. Biochem. Genet. 23:105-113.

27. Watanobe, T., Ishiguro, N., Nakano, M., Matsui, A., Hongo, H., Yamazaki, K. and Takahashi, O. 2004. Prehistoric Sado Island populations of Sus scrofa distinguished from contemporary Japanese wild boar by ancient mitochondrial DNA. Zoolog. Sci. 21:219-228.

28. Wilson, A. C., Cann, L., Carr, S. M., George, M. and Gyllensten, U. B. 1985. Mitochondrial DNA and two perspectives on evolutionary genetics. Biol. J. Linn. Soc. 26:375-400.

29. Yang, J., Wang, J., Kijas, J., Liu, B., Han, H., Yu, M., Yang, H., Zhao, S. and Li, K. 2003. Genetic diversity present within the near-complete mtDNA genome of 17 breeds of indigenous Chinese pigs. J. Hered. 94:381-385.

30. 조인철, 정용환, 정진관, 성필남, 김병우, 이정규, 전진태. 2003. Single stranded conformation polymorphism 분석에 의한 돼지 Duroc 품종의 미토 콘드리아 DNA 유전적 변이. 한국동물자원과학 회지. 45:911-916.

(접수일자 : 2004. 10. 1. / 채택일자 : 2004. 12. 15.) 